\title{
Evaluation of phytoconstituent of balanites aegyptiaca (I) del leaves and fruit-mesocarp extracts
}

\begin{abstract}
Balanites aegyptiaca $(L)$ Del is a medicinal plant used in several folk medicines and as food condiment etc in Africa. Therapeutic properties of medicinal plants depend on the varieties of chemical substances possess. This study aimed at investigating chemicals profile of Balanites aegyptiaca (L) Del extract. Defatted dried powdered Balanites aegyptiaca (L) Del leaves and fruit-mesocarp were extracted with ethanol followed by petition with ethyl acetate and water $(1: 1 \mathrm{v} / \mathrm{v})$ then separated. Aqueous fractions obtained were subjected to column fractionation where methanol subsfractions were analysis by GC-MS. Results of the study showed that extracts of Balanites aegyptiaca (L) Del leaves and fruit-mesocarp contained various phytochemical compounds. Among the phytochemicals identified were aliphatic alcohols, fatty acids and phenolic compounds. The study observed chemicals (phenolics) in the plant's parts are unequally concentrated; the leaves has more phenolics than the fruit-mesocarp. In conclusion, the study showed phenolic compounds and fatty acids are the most abundant in the plant parts which might probably accounted for the vast medicinal properties and the nutritional values.
\end{abstract}

Volume I Issue $6-2017$

\author{
Daniel Mhya Hassan,' Anigo KM, ${ }^{2}$ Umar IA, ${ }^{2}$ \\ Alegbejo $\mathrm{JO}^{3}$ \\ 'Department of Med Biochemistry, Abubakar Tafawa Balewa \\ University Bauchi, Nigeria \\ ${ }^{2}$ Department of Biochemistry, Ahmadu Bello University Zaria, \\ Nigeria \\ ${ }^{3}$ Department of Pediatric, Ahmadu Bello University Teaching \\ Hospital Zaria, Nigeria
}

\section{Correspondence: Daniel Mhya Hassan, Department of Medicinal Biochemistry, Abubakar Tafawa Balewa University} Bauchi, Nigeria, Tel 08039652964, Email dmhassan@atbu.edu.ng

Received: May 26, 2017 | Published: December 08, 2017

Keywords: evaluation, phytoconstituent, balanites aegyptiaca (1) del, leaves, fruitmesocarp, extracts

\section{Introduction}

Balanites aegyptiaca (L) Del is a medicinal plant used in several folk medicines and as food condiment etc Africa. ${ }^{1}$ Medicinal plants contain large varieties of chemical substances which possess important therapeutic properties that can be utilized in the treatment of human diseases. $^{2}$ There are several reports in the literature regarding the chemical components of extracts prepared from plants which may be useful to humans.

Balanites aegyptiaca (L) Del (Zygophyllaceae), also known as 'desert date' in English, is a plant that grows in Sahel-Savanna regions and drier parts of middle-belt zones of Nigeria. It grows to 6 to $10 \mathrm{~m}$ in height, is highly resistant to stresses such as sandstorms and heat waves, and grows with minimal available moisture. It is found in all parts of the country but mostly in the Northern region. It is known as 'Aduwa' in Hausa, 'Utazi' in Igbo, and 'Teji' in Yoruba. Balanites aegyptiaca (L) Del has a long history of traditional uses for wide ranges of disease. ${ }^{3}$ Anti-diabetic activity of Balanites aegyptiaca $(L)$ Del extracts have been reported in both diabetic mice and rats. ${ }^{4,5,6,7}$ Al-Malki et al. ${ }^{8}$ have reported antioxidant potential of Balanites aegyptiaca (L) Del in combating disease. Studies have also reported that Balanites aegyptiaca (L) Del have been used as folk medicine in many regions of Africa and Asia. ${ }^{1,9,10}$ Literature have reported antifeedant, molluscicide, anthelminthic, and contraceptive activities of Balanites aegyptiaca (L) Del extracts. ${ }^{11,12}$

Phytochemical investigation of Balanites aegyptiaca $(L)$ Del parts revealed the presence of some important chemical compounds like polyphenols; coumarins and quercetins in the leaves, alkaloids and coumarins were seen in the stem-bark while rutins was found in the fruit among others. ${ }^{13,14}$ Information on variety of chemical constituent of Balanites aegyptiaca (L) Del parts are insufficient. Hence, this study investigated chemical constituents of Balanites aegyptiaca leaves and fruit-mesocarp for the purpose of nutritional and pharmaceutical utilizations. Our study showed phenolic compounds like eugenol, transisoeugenol etc and fatty acids (oleic acid) are abundant in the plant particularly the leaves and this may accounted for vast medicinal properties and nutritional values of the plant.

\section{Materials and methods}

\section{Chemicals/Reagents}

All chemicals/reagents used were of analytical grade and were obtained from Sigma Aldrich, USA.

\section{Plant collection}

Balanites aegyptiaca (L) Del Leaves were collected from Gubi village (latitude $10^{\circ} 45^{\prime} \mathrm{N} \&$ longitude $9^{\circ} 82^{\prime} \mathrm{E}$ ) in Bauchi, Bauchi state. It was identified and authenticated by Mr. Namach Sunusi of the Herbarium Unit, Department of Biological Science, Ahmadu Bello University Zaria. A voucher specimen (voucher no: 900175) was deposited in the herbarium of the Department.

\section{Plant extraction/fractionation}

Plant sample defattening and extraction was performed as done by Jung et al. ${ }^{15}$ and Govorko et al. ${ }^{16}$ with modification in choice of the extraction temperature $\left(60^{\circ} \mathrm{C}\right)$. Seven hundred and fifty gram $(750 \mathrm{~g})$ powdered of each plant part was defatted for 2 hours with $1200 \mathrm{ml}$ hexane on mechanical shaker. The hexane solvent was discarded, and the defatted samples were air-dried then exactly $200 \mathrm{~g}$ each of the defatted plant leaves and fruit-mesocarp were mixed with $2000 \mathrm{ml}$ of $80 \%$ ethanol and heated to $60^{\circ} \mathrm{C}$ for 2 hours. The extraction was continued for an additional 10 hour at $20^{\circ} \mathrm{C}$. The mixture was filtered through a cheese cloth and resulting ethanol extract was air-dried. The procedure was repeated twice with same amount of defatted plant leaves and fruit-mesocarp. The ethanol extract of the leaves and fruitmesocarp obtained were dissolved in water $(500 \mathrm{ml})$ and partitioned 
with ethyl acetate $(500 \mathrm{ml})$ at $20^{\circ} \mathrm{C}$ for 2 hours then separated using a separating funnel $(1000 \mathrm{ml})$. Each fraction was concentrated using a rotary evaporator at $40^{\circ} \mathrm{C}$ and air dried. The dried extract-fractions of various parts of Balanites aegyptiaca were stored in air-tight containers and kept in a refrigerator at $4^{\circ} \mathrm{C}$ until used.

\section{Gas chromatograph-mass spectrometry analysis}

Analysis of Balanites aegyptiaca (L) Del extract was carried out by using a Shimadzu GC-MS equipped with silica type DB1 capillary column $(30 \mathrm{~m} \times 0.25 \mathrm{~mm}$ i.d. $)$, film thickness $0.1 \mu \mathrm{m}$. The temperature of injector was $300^{\circ} \mathrm{C}$ and the oven temperature was $300^{\circ} \mathrm{C}$. Helium $(99.9 \%)$ was used as the carrier gas at a flow rate of $0.90 \mathrm{~mL} / \mathrm{min}$. Samples of $2 \mu \mathrm{L}$ of Balanites aegyptiaca (L) Del were injected. Table I Phytochemicals identified in methanol subfraction derived from ethanol aqueous-fraction of balanites aegyptiaca leaves by GC-MS analysis (matching library of $\geq 80 \%$ )

\section{Results and discussion \\ Gas chromatograph-mass spectrometry analysis}

Figure 1 show result of the GC-MS chromatogram of Balanites aegyptiaca (L) Del leaves extract. The components in the extract were detected at the retention time in the range from 1-26min. The total components detected were 78 types. Table 1 shows basic components in the extract of the plant's leaves; 3 aliphatic aldehyde, 4 fatty acids, 4 phenolic compounds and others. Figure 2 shows result of the GCMS chromatogram of Balanites aegyptiaca (L) Del fruit-mesocarp extract. The components in the extract were detected at the retention time in the range from 1-26min. The total components detected were 37 types. Table 2 shows basic components in the extract of the plant's fruit-mesocarp; 4 aliphatic alcohols, 5 fatty acids and a phenolic

Aliphatic aldehydes

36

37

13.929

16.364

24.538

3.08

0.81

Fatty acids

\section{Phenolic compounds}

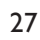

$\begin{array}{ll}\text { 7-hexadecenal } & 95 \\ \text { 9-octadecenal } & 95 \\ \text { 2-hydroxy-9, I7-octadecenienal } & 94\end{array}$

2-hydroxy-9, I 7-octadecenienal

$\begin{array}{ll}\text { hexadecenoic acid } & 80 \\ \text { oleic acid } & 86 \\ \text { Il -octadecenoic acid } & 99 \\ \text { glycidyl palmitate } & 95\end{array}$

2-methoxy-4-vinylphenol 95

2,6-dimethoxyphenol 83

2-methoxy-3(-2-propenyl)-phenol 98

2-methoxy-4-(I-propenyl)-phenol 99

\section{Others}

$\begin{array}{lllll}6 & 3.253 & 0.43 & \text { pyridine } & 83 \\ 19 & 8.576 & 0.14 & \text { benzyl alcohol } & 97 \\ 26 & 11.433 & 0.05 & \text { methyl salicylate } & 95 \\ 46 & 16.375 & 0.57 & 3 \text {-eicosene } & 91 \\ 48 & 16.741 & 0.16 & 2 \text {-methyl-Z,Z, I3-octadecadienol } & 90 \\ 49 & 16.91 & 0.6 & 2 \text {-methyl-2,5-dimethoxybenzaldehyde } & 80 \\ 50 & 17.134 & 0.05 & \text { cyclopropaneoctanal, 2-octyl } & 97\end{array}$


Table 2 Phytochemicals identified in methanol subfraction derived from ethanol aqueous-fraction of Balanites aegyptiaca Fruit-mesocarp by GC-MS analysis

Peaks Retention time (Min) Peak area in \% Name of compound Aqual factor

\section{Aliphatic alcohols}

$\begin{array}{lllll}7 & 7.799 & 0.05 & \text { 2-nitro-tertiary butanol } & 38 \\ 17 & 20.269 & 1.89 & \text { 2-octanol } & 35 \\ 26 & 23.562 & 13.12 & \text { 2-hexanol } & 14 \\ 28 & 23.852 & 1.32 & \text { 4-ethyl-3-octanol } & 38\end{array}$

\section{Fatty acids}

$\begin{array}{lllll}1 & 0.501 & 0.05 & \text { II, I4-eicosadienoic acid } & 46 \\ 10 & 17.232 & 0.12 & 9,12 \text {-octadecadienoic acid } & 95 \\ 12 & 15 & 0.7 & 9 \text {-octadecadienoic acid } & 70 \\ 13 & 18.668 & 0.23 & \text { oleic acid } & 53 \\ 32 & 24.046 & 5 & \text { glycidyl palmitate } & 95 \\ \text { Phenolic compound } & & & \\ 8 & 13.385 & 0.04 & \text { 2-methoxyl-4-vinylphenol } & 91\end{array}$

Abundance

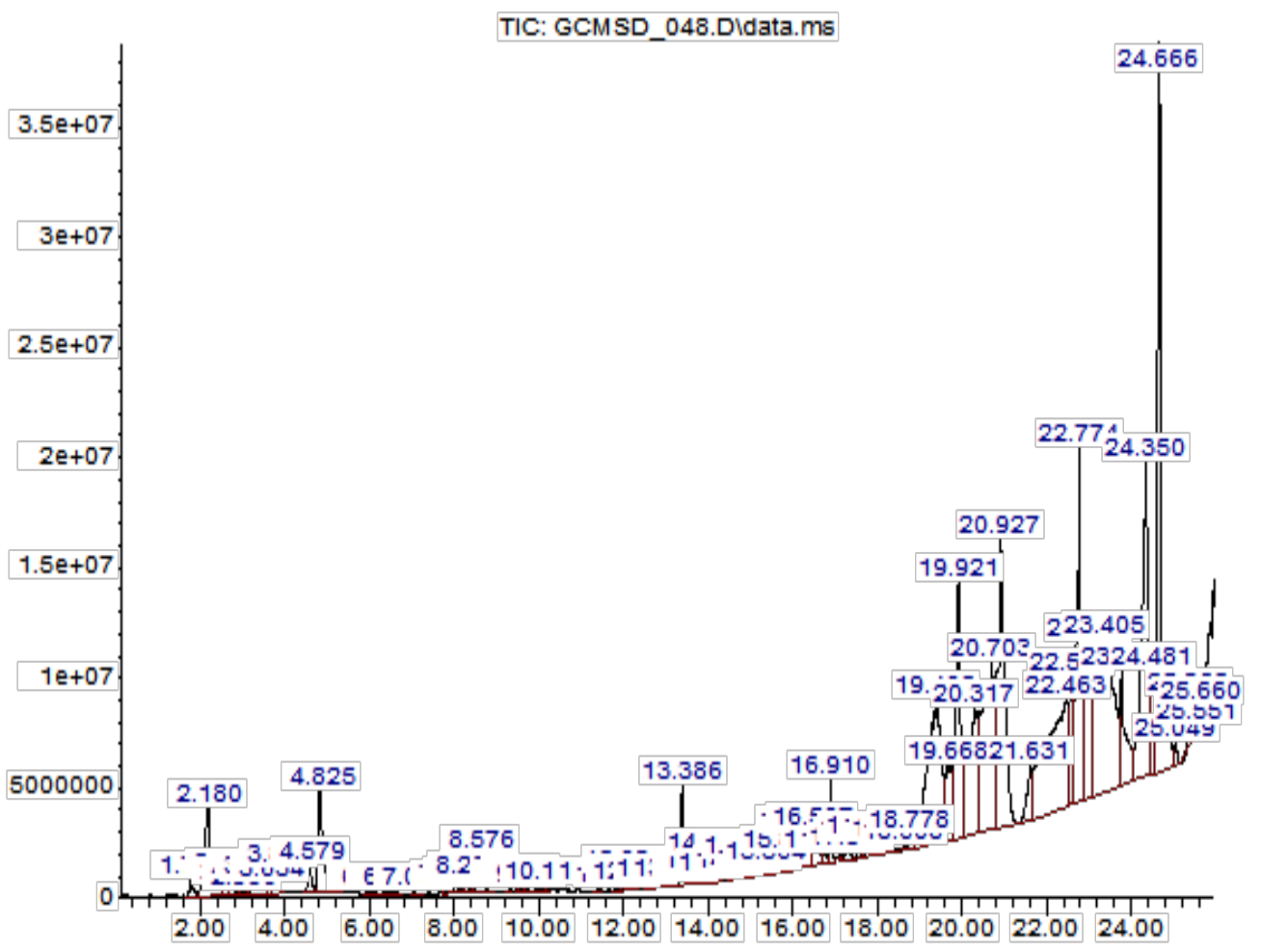

TIme- -

Figure I GC-MS chromatogram of methanol fraction derived from ethanol aqueous-fraction of balanites aegyptiaca Leaves. 


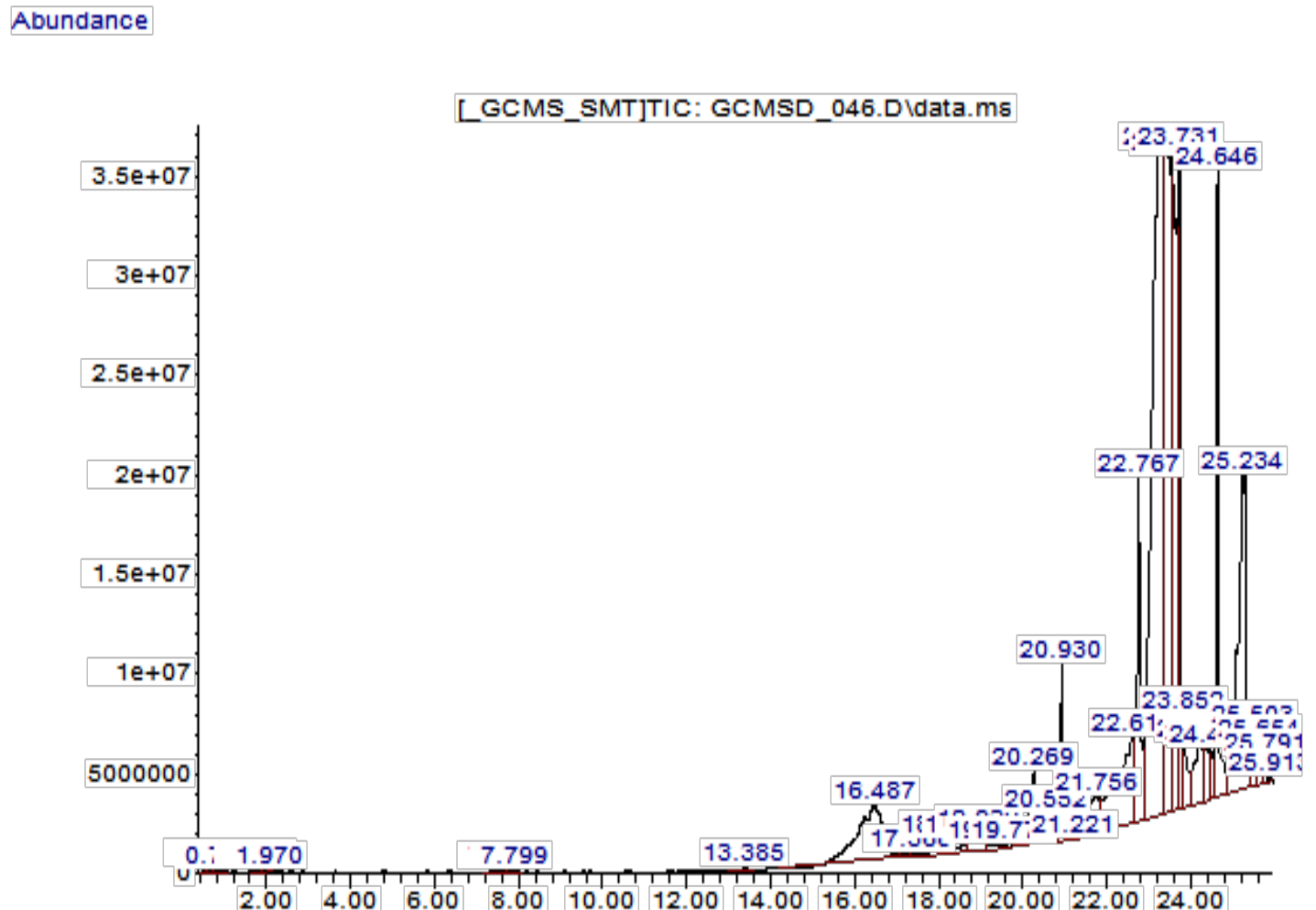

TIme---

Figure 2 GC-MS chromatogram of methanol subfraction derived from ethanol aqueous-fraction of balanites aegyptiaca fruit-mesocarp.

Among the identified compounds, phenolics have been reported to account for various pharmacological or biological activities. It was reported that phenolic compounds exert antioxidant, antidiabetic, anticancer etc. ${ }^{15,16,17,18}$ Eugenol and isoeugenol, phenolic compounds identified from Balanites aegyptiaca (L) Del's extracts in our study have been reported to exert antidiabetic activity among other pharmacological roles. ${ }^{19,20}$ Based on this, one may suggests that the phenolic compounds identified from Balanites aegyptiaca (L) Del account for its vast medicinal properties particularly antidiabetic activity. Eugenol and isoeugenol as well as other phenolics were for the first time being identified in Balanites aegyptiaca $(L)$ Del leaves extract. Al-Malki et al. ${ }^{21}$ have identified 2 phenolic (vanillic and syringic) from Balanites aegpytiaca fruit extract.

\section{Conclusion}

The study specified that extracts of Balanites aegyptiaca (L) Del leaves and fruit-mesocarp contained various phytochemical compounds. It showed that the phytochemicals were unequally concentrated in the plant's parts. Phenolic compounds like eugenol, isoeugenol etc were noticed to be concentrated in the plant's leaves while fatty acid like oleic acid was in both plant parts. Presence of these phytochemical may account for the vast medicinal and nutritional properties of Balanites aegypticaca Del.

\section{Acknowledgements}

I wish to appreciate the effort of Mallam Adamu Mohammed from the Department of Pharmagonosy, ABU Zaria, Nigeria for his assistance in plant sample extraction/fractionation. My appreciation to Mr. Bashir Musa from the Multi-User Research Laboratory, ABU Zaria for his assistance in sample analyses using GC-MS and FTIR.

\section{Conflict of interest}

The author declares no conflict of interest.

\section{References}

1. Hall JB, Walker DH. Balanites aegyptiaca (L) Del Monograph. School of Agricultural and Forest Science. UK: University of Wales; 1991. p. $1-12$.

2. Akinpelu DA, Aiyegoro OA, Okoh AI. In vitro antimicrobial and phytochemical properties of crude extract of stem bark of Afzelia africana (Smith). Afr J Biotechnol. 2008;7(20):3665-3670.

3. Chothani DL, Vaghasiya HU. A review on Balanites aegyptiaca (L) Del (desert date): phytochemical constituents, traditional uses, and pharmacological activity. Pharmacogn Rev. 2011;5(9):55-62.

4. Mansour HA, Newairy AA. Amelioration of impaired renal function associated with diabetes by Balanites aegyptiaca fruits in streptozotocininduced diabetic rats. J Med Res Inst. 2000;21(4):115-125.

5. Samir AM, Zaahkouk S, Rashid ZA, et al. Anti-diabetic properties of water and ethanolic extract of Balanites aegyptiaca fruits flesh in senile diabetic rats. Egyptian Journal of Hospital Medicine. 2003;10:90-108.

6. George DH, Ali HK, El Abbas OA. Evaluation of the biological activity of Balanites aegyptiaca (L) Del Saponin in the control of type 11 diabetes mellitus on rats and the growth of Escherichia coli. Ahfad J Women Change. 2006;23:2

7. Motaal AA, Shaker S, Haddad PS. Antidiabetic Activity of Standardized Extract of Balanites aegyptiaca (L) Del Fruits using Cell-based Bioassays. Parmacognosy Journal. 2012;4(30):20-24.

8. Al-Malki AL, Barbour EK, Abullnaja KO, et al. Management of hyperglycemia by ethyl acetate extract of Balanites aegyptiaca Del (Desert Date). Molecules. 2015;20(8):14425-14434. 
9. Mohamed AM, Wolf W, Spiess WEL. Recovery and characterization of Balanites aegyptiaca Del. Kernel proteins: Effect of defatting, air classification, wet sieving and aqueous ethanol treatment on solubility, digestibility, amino acid composition and sapogenin content. Molecular Nutrition \& Food Research. 2000;44(1):7-12.

10. Mohamed AM, WolfW, Spiess WE. Physical, morphological and chemical characteristics, oil recovery and fatty acid composition of Balanites aegyptiaca (L) Del Kernels. Plant Foods Hum Nutr. 2002;57(2):179-89.

11. Liu HW, Nakanishi K. The structure of Balanites: Potent molluscides isolated from Balanites aegyptiaca. Tetrahedron. 1982;38(4):513-519.

12. Kamel MS, Ohtani K, Kurokawa T, et al. Studies on Balanites aegyptiaca (L) Del fruits: An antidiabetic Egyptian folk medicine. Chem Pharm Bull (Tokyo). 1991;39(5):1229-1233.

13. Salwa AM, El Hadidi MN. Flavonoids of Balanites aegyptiaca (Balanitaceae) from Egypt. Plant Syst Evol. 1988;160(3-4):153-158.

14. Sarker SD, Bartholomew B, Nash RJ. Alkaloids from Balanite aegyptiaca. Fitoterapia. 2000;71(3):328-330.

15. Jung MY, Jeon BS, Bock JY. Free, esterified and insoluble bound phenolic acids in white and red ginsengs (Panax ginsengC.A. Meyer). Food Chem. 2002;79(1):105-111.
16. Govorko D, Logendra S, Wang Y, et al. Polyphenolic compounds from Artemisia dracunculus L. inhibit PEPCK gene expression and gluconeogenesis in an H4IIE hepatoma cell line. Am J Physiol Endocrinol Metab. 2007;293(6):1503-1510.

17. Mhya DH, Anigo KM, Umar IA, et al. Evalaution of hypoglycemic potential of extracts of Balanites aegyptiaca parts. Int $J$ of Innovative and Advanced Studies. 2016;3(9):1-5.

18. Jeong JB, Jeong HJ. 2-Methoxy-4-vinylphenol can induce cell cycle arrest by blocking the hyper-phosphorylation of retinoblastoma protein in benzo[a]pyrene-treated NIH3T3 cells. Biochem Biophys Res Commun. 2010;400(4):752-757.

19. Srinivasan S, Sathish G, Jayanthi M, et al. Ameliorating effect of eugenol on hyperglycemia by attenuating the key enzymes of glucose metabolism in streptozotocin-induced diabetic rats. Mol Cell Biochem. 2014;385(1-2):159-168.

20. Singh P, Jayaramaiah RH, Agawane SB, et al. A Potential Dual Role of Eugenol in Inhibiting Advanced Glycation End Products in Diabetes: Proteomic and Mechanistic Insights. Sci Rep. 2016;6:18798.

21. Al-Malki AL, Barbour EK, Abullnaja KO, et al. Management of hyperglycemia by ethyl acetate extract of Balanites aegyptiaca (Desert Date). Molecules. 2015;20(8):14425-14434. 